\title{
PENGGUNAAN METODE LATTICE DALAM MENGATASI RENDAHNYA KEMAMPUAN BERHITUNG OPERASI PERKALIAN
}

\author{
Nur Khulaifatur Rosidah Solikin ${ }^{1}$, Dyah Ayu Sulistyaning Cipta ${ }^{2}$, \\ Asri Putri Anugraini ${ }^{3}$ \\ Pendidikan Matematika, IKIP Budi Utomo Malang1,2,3
}

khulaifatur@gmail.com ${ }^{1}$, dyahayu.esce@gmail.com², asriputri080989@yahoo.com³

\begin{abstract}
Abstrak
Salah satu permasalahan yang sering dihadapi peserta didik ialah rendahnya kemampuan berhitung operasi perkalian. Salah satu penyebab kondisi ini adalah masih kurangnya pemahaman konsep perkalian dua digit angka dan prosedur mengerjakan. Sejalan dengan itu, dengan adanya penelitian ini diharapkan dapat mengatasi rendahnya kemampuan berhitung operasi perkalian peserta didik dengan menerapkan metode lattice. Tujuan penelitian ini ialah mendeskripsikan penggunaan metode lattice dalam mengatasi rendahnya kemampuan berhitung operasi perkalian. Penelitian ini merupakan penelitian kualitiatif. Tahapan pada penelitian ini terbagi menjadi beberapa treatment, dimana setiap treatment peserta didik mendapatkan perlakuan dari pengenalan metode lattice sampai menggunakan dengan mahir metode lattice. Hasil penelitian ini menunjukan para peserta didik sangat tertarik dengan metode yang baru mereka kenal. Mereka mampu menyelesaikan secara mandiri soal operasi perkalian setelah melalui empat treatment yang telah diberikan. Pada akhir treatment ratarata yang dicapai peserta didik ialah 84,30 dengan presentase ketuntasan mencapai $96,56 \%$ dan kemampuan berhitungnya mengalami peningkatan 0.81 (kategori tinggi).
\end{abstract}

Kata Kunci: kemampuan berhitung, operasi perkalian, metode lattice

\begin{abstract}
One of the problems often faced by students is the low ability to calculate multiplication operations. One of the causes of this condition is still a lack of understanding of the two-digit multiplication concept and the procedure for working on it. In line with this, the existence of this study is expected to overcome the low ability to calculate multiplication operations of students by applying the lattice method. The aim of this study is describe of using the lattice method in overcoming the low ability to calculate multiplication operations. This research is a qualitative study. The stages in this study are divided into several treatments, where each treatment students get treatment from the introduction of the lattice method to use the advanced lattice method. The results of this study show that students are very interested in the new methods they know. They were able to complete independently the multiplication
\end{abstract}


operation after going through four treatments that had been given. At the end of the treatment the average student achieved was 84.30 with a percentage of completeness reaching $96.56 \%$ and his numeracy ability increased by 0.81 (high category).

Keywords: counting ability, multiplication operations, lattice method

\section{PENDAHULUAN}

Pendidikan adalah suatu usaha sadar untuk menyiapkan peserta didik agar berperan aktif dan positif mengembangkan potensi dirinya untuk sekarang dan akan datang (Fokusmedia, 2006: 58). Materi yang selalu didapat ketika menempuh pendidikan formal ialah berhitung, di mana berhitung merupakan bagian dari mata pelajaran matematika. Konsep dasar dalam matematika terdiri dari operasi penjumlahan, pengurangan, pembagian dan perkalian bilangan asli.

Kemampuan yang harus dikuasai oleh peserta didik agar mahir dalam mata pelajaran matematika ialah kemampuan memahami konsep. Kenyataan di lapangan menunjukkann kemampuan ini kurang terasah dengan baik, banyak peserta didik mengandalkan metode hapalan materi. Banyak guru dalam pelaksanaan pengajaran operasi perkalian masih mengunakan metode hafalan, sehingga konsep operasi perkalian tidak dipahami dengan baik. Hal ini berdampak kepada peserta didik yang cepat lupa dalam mengoperasikan perkalian bilangan asli. Berdasarkan observasi saat pembelajaran materi operasi perkalian bilangan lebih dari satu digit, guru cenderung sering menerapkan metode perkalian bersusun, tanpa ada variasi motode lain.

Seiring perkembangan ilmu pengetahuan, khususnya dalam matematika. Metode pengoperasian perkalian bilangan asli banyak sekali yang dapat digunakan. Metode perkalian yang ada diantaranya ialah metode jarimatika, metode perkalian bersusun, metode sempoa, metode garis, metode lattice dan sebagainya. Berdasarkan Zubaidah (2015) metode lattice dapat meningkatkan hasil belajar matematika peserta didik sekolah dasar. Hapriani (2018) juga mengatakan bahwa terdapat pengaruh yang baik dalam penggunaan metode lattice terhadap hasil belajar peserta didik. Metode lattice adalah metode perkalian yang disajikan dalam bentuk tabel, antara puluhan dan satuan dipisahkan (Mujib dkk, 2013: 2). Metode lattice berbeda dengan metode perkalian bersusun, dimana hasil hitung sudah ditempatkan dalam kotak tertentu sehingga mengurangi kesalahan yang bisa peserta didik lakukan dalam menyelesaikan soaloperasiperkalian bilangan asli. Untuk itu, metodeperkalian lattice merupakan suatu metode alternatif yang dapat diberikan kepada peserta didik. Terlebih bagi peserta didik yang 
mengalami kesulitan dalam menyelesakan soal operasi perkalian menggunakan metode bersusun.

\section{METODE PENELITIAN}

Penelitian ini menggunakan metode penelitian kualitatif yang bertujuan untuk mengetahui cara menggatasi rendahnya kemampuan menghitung pada peserta didik. Menurut Moleong (2013: 6) bahwa penelitian kualitatif adalah suatu penelitian yang bertujuan untuk memahami fenomena tentang apa yang dialami oleh subjek penelitian, secara holistik dan dengan cara deskriptif dalam bentuk kata-kata danbahasa.

Akan tetapi pendekatan yang digunakan adalah penelitian tindakan kelas (PTK) yang memiliki karakteristik mendeskripsikan semua informasi secara apa adanya, dan peneliti berperan sebagai instrumen utama dalam penelitian. PTK dipilih ddikarenakan ciri khasnya yang dimiliki yaitu melakukan tindakan berulang-ulang untuk memperoleh hasil lebih baik. Hal tersebut sesuai pendapat Ebbut (dalam Lelie, 2009:32) bahwa penelitian tindakan kelas merupakan studi sistematis yang dilakukandalam upayamemperbaikipraktik-praktik dalam pendidikan dengan melakukan tindakan praktis serta refleksi dari tindakantersebut.

Lokasi penelitian bertempat di MI Al Khoiriyah Tirtomoyo. Populasi yang diambil ialah peserta didik kelas V A. Sedangkan subjek data dalam penelian ini dipilih berdasarkan tes diagnostik yang dilakukan diawal sebelum penelitian dilakukan. Dari hasil tes diagnostik terpilih enam peserta didik yang menjadi subjek data penelitian, didasarkan skor yang didapatkan berada dibawah 10 dari 100 .

Sumber data penelitian ini didapatkan dari pengamatan instrumen utama dan instrumen bantuan didukung oleh dokumentasi. Instrumen bantuan yang digunakan dalam penelitian yaitu observasi, tes, pedoman wawancara. Adapun instrumen utamanya ialah peneliti sendiri yang berperan sebagai tenaga pengajar. Tahapan yang dilakukan dalam penelitian terdiri dari tahap perencanaan, tahap pelaksanaan yang dimulai dengan tes diagnostik dilanjutkan dengan beberapa treatment dan tahapan evaluasi.

Dikarenakan penelitian ini menggunakan metode pendekatan PTK maka ada beberapa siklus yang terjadi. Siklus dihentikan ketika indikator keberhasilan sudah tercapai. Menurut Djamarah (2000: 97) urutan keberhasilan pembelajaran ada empat terdiri atas (i) istimewa; (ii) baik sekali;(iii) baik; dan (iv) kurang. Penelitian dianggap berhasil jika (i) sekurang-kurangnya 70\% peserta didik mencapai kriteria keberhasilan belajar KKM 65 atau lebih dan (ii) nilai rata-rata setiap tes mengalami 
kenaikan.

\section{HASIL PENELITIAN DAN PEMBAHASAN}

Ada dua variabel yang digunakan yaitu variabel independen (metode lattice) dan variabel dependen (kemampuan berhitung peserta didik). Penelitian dilaksanakan pada siswa di kelas VA MI Al Khoiriyah. Metode lattice berguna untuk menghitung operasi perkalian dua digit angka atau lebih. Tahapan sebelum melaksanakan penelitian ialah tahapan penggumpulan data awal, perencanaan dantahap pelaksanaanpenelitian.

Penelitian ini membutuhkan peserta didik yang sudah mengenal materi perkalian dasar. Untuk menentukan sampel penelitian dilakukan tes diagnostik. Seluruh peserta didik kelas VA mendapat lima soal operasi perkalian. Tes diberikan untuk mengetahui kemampuan awal peserta didik pada operasi perkalian. Dari 29 total peserta didik kelas VA dipilih enam peserta didik dengan nilaidibawah10 untuk menjadi subjek penelitian, ratarata tes diagnostik keseluruhan peserta didik hanya 17,89 .

Penerapan metode lattice dilakukan pada beberapa treatment yang terdapat pada siklus pembelajaran. Setiap siklus terdiri dari dua pertemuan. Materi yang dipilih untuk penelitian ini ialah operasi hitung perkalian pada bilangan pecahan. Sebelum melakukan treatment yang dilakukan dalambentuk pembelajaran peneliti menyusun RPP, menyiapkan soal latihan guna mengetahui ke efektifan penggunaan metode lattice dalam operasi perkalian,dan mempersiapkan lembarobservasi.

Treatment pertama, peneliti menperkenalkan kepada peserta didik metode lain dalam menghitung operasi perkalian dua digit angka atau lebih yaitu dengan menggunakan metode lattice. Memperkenalkan metode ini meliputi cara kerja perkalian lattice, dan membantu peserta membuat tabel bantu perkalian metode lattice.

Pada treatment kedua, peneliti menjelaskan cara menyelesaikan soal operasi hitungperkalian dengan menggunakan metode lattice. Peserta didik dibimbing menggunakan metode lattice dengan membuat garis melintang pada tabel yang sudah dibuat, dilanjutkan dengan penempatan hasil perkalian dan cara menjumlahkan hasil perkalian yang sudah didapat. Setelah itu peneliti membagikan soal tes yang sudah dilengkapi dengan tabel perkalian untuk membantu menyelesaikan soal tersebut. Dalam proses penyelesaian soal tes, peneliti berkeliling untuk membantu sampel memahami penggunaan metode lattice.

Treatment ketiga, merupakan lanjutan dari treatment sebelumnya, dimana pada treatment kedua peserta didik mengerjakan soal tes dengan disertai tabel untuk meletakkan hasil perkaliannya. Namun, treatment kali 
ini mengharuskan peserta didik menyelesaikan soal bersama-sama mulai dari membuat tabel untuk penempatan hasil kali dilanjutkan dengan menjumlah apa yang sudah diperoleh. Peserta didik saling membantu untuk menyelesaikan soal tersebut kemudin mempresentasikanhasil kerjasama tadi kepada temannya yang berada dibangku.

Treatment empat ialah treatment terakhir yang diberikan oleh peneliti kepada peserta didik. Peserta didik menerima soal, soal tersebutdikerjakan secara individual, dan tanpa ada bantuan tabelseperti pada treatment sebelumnya. Peneliti berkeliling untuk melihatpenerapan treatment sebelumnya yang digunakan pada treatment kali ini.

Penelitian ini bertujuan untuk mengatasi rendahnya kemampuan berhitung operasi perkalian dengan menggunakan metode lattice. Pada saat tes diagnostik dapat diketahui bahwa kemampuan berhitung operasi perkalian masih sangat rendah, hal tersebut dapat dilihat dari skor yang didapat saat tes. Hasil tes diagnostik ini juga menunjukkan masalah yang menyebabkan peserta didik mengalami kesulitan, yaitu: (a) peserta didik belum hafal perkalian satuan antara satu sampaisembilan, (b) peserta didik kurang semangat dan minat saat mengerjakan soal tes, (c) banyaknya peserta didik yang masih perlu mengingat materi perkalian yang sudah lama belum dipelajari lagi, (d) kurang pahamnya peserta didik dalam menyelesaikan soal perkalian puluhan dan ratusan dengan metode bantu perkalian yang lain, dan (e) adanya kesalahan penafsiran soal perkalian.

Namun setelah melewati beberapa kali treatment mereka mulai mampu mengatasi itu sendiri. Karena selama proses treatment sampel mendapat arahan dari peneliti dalam menyelesaikan soal. Hal tersebut mampu mendukung peserta didik untuk mengetahui kemampuan dan kesalahan saat mengerjakan soal tes. Kemampuan berhitung peserta didik dapat diperbaiki dengan diberikan treatment yang dilakukan secara berulang kepada peserta didik.

Berdasarkan hasil penelitian dapat disimpulkan bahwa peserta didik yang menjadi subjek penelitian mengalami perkembangan. Berikut merupakan jabaran perkembangan sampel yang telah dipilih saat proses treatment: pada saat tes diagnostik 6 subjek penelitian mendapatkan skor di bawah 10. Pada treatment pertama sampel sudah memahami cara membuat tabel bantu akan tetapi masih kesulitan pada penggunaan tabel. Treatment kedua sampel mulai memahami cara penempatan angka meskipun masih ada kesalahan dalam menjumlahkan. Treatment ketiga sampel sudah mampu menyelesaikan soal operasi perkalian menggunakan metode lattice meskipun membutuhkan waktu dalam menyelesaikan. Pada treatment terakhir sampel mampu menyelesaikan secara mandiri soal operasi perkalian. Hal tersebut didukung dengan adanya peningkatan nilai rata-rata 
yang diperoleh dari 17,89 menjadi 84,30 . Pada akhir treatment rata-rata yang dicapai peserta didik ialah 84,30 dengan presentase ketuntasan mencapai 96,56\% dan kemampuan berhitungnya mengalami peningkatan 0.81 (kategori tinggi).

Berdasarkan hasil penelitian tersebut dapat dikatakan bahwa metode lattice mampu memberikan peningkatan terhadap kemampuan peserta didik dalam berhitung operasi perkalian sehingga nilai matematika peserta didik meningkat. Hal ini sesuai dengan pendapat Zubaidah (2015) bahwa metode lattice dapat meningkatkan hasil belajar matematika peserta didik

\section{KESIMPULAN DAN SARAN}

Pada tahap tes diagnostik peserta didik masih memiki kemampuan berhitung yang lemah dan kurangnya pemahaman cara menyelesaikan operasi perkalian dengan cara bersusun. Hasil treatment pertama mereka mampu memahami kinerja metode lattice. Pada treatment ketiga sampel mampu membenahi kesalahan yang dilakukan pada treatmentsebelumnya. Pada treatment terakhir sampel sudah mampu menyelesaikan soal secara mandiri.

Berdasarkan kesimpulan di atas, peneliti memberikan saran sebagai berikut. Metode lattice dapat digunakan sebagai opsi dalam mengajarkan operasi perkalian. Guru diharapkan dapat menambahkan variasi metode berhitung yang bisa dibagikan kepada peserta didik dengan adanya metode ini.

\section{DAFTAR PUSTAKA}

Djaramah, Saiful Bahri. (2000). Guru dan Anak Didik dalam Interaksi Edukatif. Jakarta: Rineka Cipta

Hapriani. (2018). Pengaruh Penggunaan Metode Lattice terhadap Hasil Belajar Siswa pada Mata Pelajaran Matematika. Skripsi. Jurusan PGMI. UIN Mataram.

Lelie. (2009). Penerapan Metode Demokrasi dalam Meningkatkan Hasil Belajar Sains pada Peserta Didik Kelas III di SDN Pahandut Seberang. Palangkaraya: Skripsi Universitas Muhammadiyah Palangkaraya.

Moleong, Lexy, J. (2007). Metode Penelitian Kualitatif. Bandung: Remaja Rosdakarya.

Mujib, Abdul dan Suparingga, Erik. (2013). Upaya Mengatasi Kesulitan Siswa dalam Operasi Perkalian dengan Metode Lattice. Makalah dipresentasikan dalam Seminar Nasional Matematika dan Pendidikan 
Matematika, Jurusan Pendidikan Matematika, FMIPA, Universitas Negeri Yogyakarta. Yogyakarta, tanggal 9 November2013.

Tim Redaksi Fokus Media. (2006). Himpunan Perundang- undangan Guru dan Dosen: dilengkapi dengan Undang-Undang RI No 20 Tahun 2013 tentang Sistem Pendidikan Nasional. Bandung: FokusMedia.

Zubaidah, dkk. (2015). Peningkatan Hasil Belajar Matematika dengan Metode Lattice di Kelas III Sekolah Dasar. Jurnal Pendidikan dan Pembelajaran, Vol 4, No.1. 